\title{
The Ethics of Contingency
}

Calcaterra's Reading of Rorty

Michela Bella

\section{(2) OpenEdition}

\section{Journals}

Electronic version

URL: http://journals.openedition.org/ejpap/2188

DOI: $10.4000 /$ ejpap.2188

ISSN: 2036-4091

Publisher

Associazione Pragma

Electronic reference

Michela Bella, "The Ethics of Contingency », European Journal of Pragmatism and American Philosophy [Online], XII-2 | 2020, Online since 14 December 2020, connection on 15 December 2020. URL : http:// journals.openedition.org/ejpap/2188; DOI : https://doi.org/10.4000/ejpap.2188

This text was automatically generated on 15 December 2020 .

\section{(c) $(1) \odot$}

Author retains copyright and grants the European Journal of Pragmatism and American Philosophy right of first publication with the work simultaneously licensed under a Creative Commons AttributionNonCommercial-NoDerivatives 4.0 International License. 


\title{
The Ethics of Contingency
}

\author{
Calcaterra's Reading of Rorty
}

\section{Michela Bella}

1 Moving from pragmatism and drawing on a fascinating and accurate interpretation of Richard Rorty's work, Rosa Calcaterra's Contingency and Normativity. The Challenges of Richard Rorty (Brill-Rodopi, 2019) proposes a philosophical investigation of the relationship between normativity and contingency. Calcaterra's longstanding familiarity with pragmatist philosophy strongly marks her attitude towards these topics and their related issues. The author takes up some of the pragmatists' constructive proposals: firstly, escaping from "univocal definitions" by shifting the discussion to the level of functional analysis. This move helps to verify the effectiveness of the plurality of notions that constitute the shared meanings of normativity and contingency. Secondly, and strictly related to the first move, the author shows how these notions belong to the "composite concreteness of the practices and the potentialities typical of the human intelligence" (Calcaterra 2019: ix).

2 The author embraces Rorty's invitation to continue developing the pragmatist and neopragmatist way of thinking. In the thematic path she traces, she relies on Rorty's work in the conviction that it allows her to collect "the big challenges resulting from the long process of dismantling of the philosophical systems of Western culture," also playing the role of "critical" spur of her pragmatist proposal. Her interpretative strategy follows the Jamesian advice to be sympathetic to the Rortyan provocations, which she tries to read more smoothly and soundly, addressing the core of his criticisms and epistemological and ethical concerns. However, Calcaterra's work goes beyond that of a skillful interpreter. Following the suggestions and challenges posed by Rortyan contingentism, the author marks her philosophical pathway exploring the theoretical proposal of a new pragmatist anthropology, one that "could be free from the narrowness of traditional metaphysics" while at the same time not being "committed to a radical skepticism on both epistemic and ethical levels" (Calcaterra 2019: ix). The general impression is that the practical and ethical aspects of Rorty's contingentism turns out to be the main focus of Calcaterra's work. More or less explicitly, the author claims it is an issue that deserves further clarification, tackling in 
significant ways several other related issues such as realism, ethical-political meliorism, and a new pragmatist anthropology that goes beyond Rorty.

\section{Pragmatist Realism and Contingentism}

3 The volume consists of six chapters. Each of them deals with a specific theme, which is essential to bring out the complex elaboration of Rortyan contingentism. In "From pragmatism to analytic philosophy and vice versa," Calcaterra offers an overview of Rorty's neopragmatist movement from the "academic ivory tower" towards an “"edifying' philosophy and a philosophical cultural criticism" (Calcaterra 2019: 2). Calcaterra examines Rorty's dialogue with both classical pragmatists and analytical philosophy. Rorty recovers James and Dewey's anti-foundationalism while reading Peirce's realism as still influenced by some metaphysical thinking. Unlike other scholars, he explains Peirce's recovery by analytical philosophy and the rejection of James and Dewey as resulting from the misunderstanding of their relationship with Kant. Rorty particularly stresses pragmatists' "breaking with the Kantian epistemological tradition," while noting that Peirce "remained the most Kantian of thinkers" (Calcaterra 2019: 3). Here, Calcaterra criticizes two of Rorty's interpretations. Firstly, the negative meaning of "theory" taken from Wittgenstein, according to which Rorty denies that pragmatists had a "theory of truth." Secondly, the author underlines how Peirce's increasingly accentuated association with the analytical philosophy which Rorty sees more and more convincingly as a contemporary variant of Kantian philosophy - nourished Rorty's criticism. Calcaterra also illustrates how Rorty's reading of Peirce and Wittgenstein's similarities revealed his non-superficial knowledge of the American pragmatist. Therefore, his choice to dismiss Peirce is not the result of a lack of knowledge, but his training at Chicago and Yale under the guidance of Hartshorne and Weiss and their metaphysical reading of Peirce and Whitehead.

4 Nevertheless, Calcaterra recalls that Rorty initially welcomed the dialogue between analytical philosophy and pragmatism for the challenge to overcome the "crucial paradox of Western philosophy," given the dyscrasia between philosophers' metaphilosophical aspiration to a neutral framework of reference and the concrete conflict between philosophical schools. In particular, Dewey's pragmatism seemed to pave the way for a philosophy that was a game of re-description of rules, thus reorienting the attention from the search for truth to the search for uninterrupted communication. On this topic, Calcaterra embraces Voparil's interpretation that the young Rorty was still ambiguous about the moral dimension's importance in pragmatism. On the one hand, "an appeal to pragmatic justification always threatens to end the dialogue"; while on the other, the "appeal to practice transfers the question of the acceptability of a philosophical program out of a metaphilosophy and into the realm of moral choice" (Voparil 2010: 13). According to Calcaterra, Rorty welcomes pragmatism for its nonskeptical attitude towards philosophy: the pragmatists proposed, instead, to reformulate the task of philosophy.

5 Turning to Rorty's relationship with analytical philosophy, Calcaterra focuses on the importance of Carnap's philosophy for Rorty's analytical training and his criticism of representationalism and foundationalism. Calcaterra dedicates great attention to the introductory essay to the collection edited by Rorty The Linguistic Turn (1967). In her 
view, it is a programmatic text in which some of the philosopher's later directions of research are already recognizable. Rorty acknowledges the theoretical value of the "linguistic strategy" as a way of tackling the "necessity of new strategies of solution for philosophical questions" (Calcaterra 2019: 14). While distinguishing between an analytical philosophy (Frege-Russell) and a linguistic philosophy (Ryle-Austin), Rorty joins them in their attempt to pursue the "project of philosophy as a rigorous science" (Calcaterra 2019: 13), thus denouncing their joint bankruptcy. If it is true, writes Calcaterra, that the philosophies centered on the linguistic turn have shown the "progressive nature of philosophy, the dynamic tendency that is typical of philosophy because of its capability to change its own tools and even its own general functions" (Calcaterra 2019: 14); at the same time, they undergo a deep crisis concerning the sense of practicing philosophy. Indeed, the philosophers of language still consider as principal the obligation to pursue the foundation of philosophy and, as anticipated, to identify philosophy with science.

6 According to Calcaterra, Rorty's change of direction towards a "new theoretical path" derives from this analysis of the current status of the philosophy of language and is characterized by two primary purposes: "revisiting the pre-analytic tradition of American philosophy, particularly pragmatism, and engaging with the European philosophies from Nietzsche and Heidegger to the French deconstructionists." (Calcaterra 2019: 14). At least two continuities with Rorty's later thinking mark this new path. First, his endorsement of the Kuhnian understanding of how scientific research makes progress, and second his "allusion to the theme of philosophy as "conversation"' (Calcaterra 2019: 15). On these leitmotifs of the Rortyan thinking, Calcaterra makes two critical clarifications. As for Kuhn, his conception of the "incommensurability between scientific theories" helps Rorty to assess the contingency of philosophical and scientific languages. This "is a key point of his thought, an intersection of the critiques of representationalist foundationalism, antirealism and ethnocentrism united in the endorsement of the Kuhnian idea that the words 'rational' and 'scientific' just indicate the fruit of an established social and ethical praxis" (ibid.).

7 As for the idea of philosophy as "conversation," Calcaterra specifies that many criticisms miss the connection with "the criterion of argumentative justification" even though "Rorty focuses continuously on this subject, counterposing the normative value of the conversational practices at work in scientific and philosophical conceptions and the modern foundationalist claims" (ibid.). Stressing Rorty's attention to the normative value of philosophical and scientific discursive practices, Calcaterra supports Rorty's way of getting out of two related bottlenecks. One is the problem of Rorty's antirealist stance; the other concerns the difficulty to discern between change and progress, keeping alive the role of philosophy.

Rorty rejects the realism/antirealism dilemma, reiterating how, from an antiessentialist perspective, the change of vocabulary contributes to redesigning what Dewey would call the "problematic situations" and introducing new problems, new philosophical issues. In short, novelties emerge in reality for logical-semantical paradigm changes that allow us to frame situations in new and unexpected ways. As to the role of philosophy, and the difficulty to distinguish between progress and change relying normativity on discursive practices, Calcaterra underlines the dimension of the social consensus that is the undeclared assumption of foundational theories. A "sufficiently large consensus" is what is pragmatically meant by "neutral perspective," 
that is the background on which foundational philosophies talk about progress in knowledge: "our conviction of having reached a neutral and indisputable point of view is always based on philosophical presuppositions aimed at a sufficiently large consensus, on which we can build new arguments and problems to debate." (Calcaterra 2019: 16). So, while talking about progress is inappropriate for Rorty, for it implies a foundational mentality, talking about changes instead should not necessarily lead to giving up the critical role of philosophy. Philosophy can "uncover" these tacit presuppositions or paradigm changes and thus contribute to understanding the emergence of new problems.

Calcaterra sporadically returns throughout the book to this crucial topic. Her perspective stresses Rorty's bond with classic pragmatists, especially James and Dewey. They were also accused of being antirealists while trying to get out from recurrent dichotomies and old ways of framing the philosophical debate. Calcaterra seems to have this connection in mind when she states in the sixth chapter, titled "Contingency and Normativity. Lines of a new pragmatic anthropology," that "Rorty underlines the necessity to dismiss the debate on realism and antirealism in so far as it tends to represent just a rhetorical scholasticism: whoever rationally and coherently uses a language refers implicitly to objective reality" (Calcaterra 2019: 115; emphasis added).

In other words, "the concreteness of linguistic practice shows the obviousness of the language-reality connection and the challenges of realism seem just to miss this obviousness, which is in fact of one piece with the conception of language as a 'tool' or - in Dewey's words - as 'the tool of tools' for human interaction with both physical and social worlds. It is important to notice that the recovering of the language-reality interlacing implies that also scientific and philosophical descriptions of so-called 'human nature' are susceptible of criticism, no less than any other form of description provided by means of our species-specific language ability." (Ibid.).

11 In the second chapter, "Linguistic pragmatism," she also deals with this aspect, arguing that "The debate between realists and antirealists or relativists, so frequent in modern and contemporary philosophy, is then judged as one of those questions that Wittgenstein suggested dissolving through an instrumental conception of language" (Calcaterra 2019: 44). Reconsidering the debate about Rorty's antirealist stance in a Wittgensteinian and in a classical pragmatist perspective, a possible question would concern more closely the relationship with James and Dewey on this point. Does the author believe that, for instance, James's answer to the fourth misunderstanding of pragmatism as an antirealist philosophy could be suitable for Rorty (given that James does not consider epistemology in the foundationalist sense meant by Rorty)?

\section{Ethics and Contingentism}

Calcaterra's analysis of Rortyan contingentism mainly deals with the ethical implications of his post-Philosophical project. Her thesis is that: the "Rortyan use of the principle of charity [as taken from Davidson] goes beyond the romantic and vaguely philanthropic perspective under which it is generally seen, and actually represents both an epistemic and an ethical criterion that gives its deepest sense to Socratic irony in a renewed contingentist philosophical approach." (Calcaterra 2019: xii). Her reading of the epistemic and ethical implications of Rortyan discourse sees contingentism as a new framework inevitably influencing how to reconsider the role of philosophical 
practice, as well as the role of philosophers: "What is at stake is the figure of the philosopher as conceived in the Platonic framework of epistème as the possessor of privileged and autonomous knowledge, counterposed to the figure of philosopher as 'inventor' of new vocabularies, that is, new logical-semantic paradigms which could improve our comprehension and action in the cultural and physical-natural world where we are actually situated." (Calcaterra 2019: 21).

Talking about Rorty's ethical engagement, a net of "ethically-qualifying concepts" come to mind, like "dialogue, the 'conversation of mankind' and solidarity" (Calcaterra 2019: xii). The importance of rethinking philosophy as one voice among others has several implications, which Calcaterra quickly mentions, but are useful to enucleate: 1) the idea that "individual and social history depends on this conversation" (ibid.). This means that humanity has an ethical duty to keep it going. 2) The idea that the advancement of human history depends on the "respect for other people's positions rather than the definitive and absolutistic claims of truth spread by the forma mentis of philosophical essentialism" (ibid.). Here emerges Rorty's proximity with the Jamesian pluralism professed in Contingency, Irony, and Solidarity (cf. CIS: 38). 3) The "epistemic awareness of the concrete difficulties involved in breaching the dividing walls that stand between human beings because of the logical-semantic systems (what he calls 'final vocabularies') on which their specific forms of life rely." (Calcaterra 2019: xii). Rorty's passage from "Philosophy" to "philosophy" is based on a historicist reading of human culture, which is inspired by classical pragmatism and continental philosophers. A historicist inclination is necessary a precondition for conversation, whereas beliefs and truths claimed to be timeless leave no room for dialogue. According to Calcaterra, what Rorty tries to pursue in American philosophy is to favor a different philosophical attitude, one that takes the place of the "metaphysical" attitude and is more prone to historicism and fallibilism. This attempt is paradigmatic of the broader postmodernist movement made in different cultural fields of his time. However, his efforts do not originate from moralism, nor are they reducible in Calcaterra's words to "the mere optimism of good intentions" (ibid.). Rorty's conceptions are instead profoundly rooted in the contingentist perspective that the author relates to Davidson's "epistemological thesis that human communication is a process irremediably involved in the contingencies [...] and so it is never guaranteed both in its dynamics and in its consequences." More specifically, she argues that Rorty adopts "Davidson's radicalization of the "principle of charity'," that is his understanding of it as "the conditio sine qua non of every kind of communication" (ibid.). In this view, Rorty's quotation at the end of the first chapter is a cornerstone of Calcaterra's ethical reading: "The only point on which I would insist is that philosophers' moral concern should be with continuing the conversation of the West, rather than with insisting upon a place for the traditional problems of modern philosophy within that conversation." (Calcaterra 2019: 21). She ethically reads his "proposal to turn the ancient ambitions for truth and indisputable principles into the philosophical practice (less ambitious but more ethically committed), of 'culture criticism"' (Calcaterra 2019: 18; emphasis added).

14 In the last chapter, "Contingency and Normativity," Calcaterra exposes her "theoretical proposal" tracing new pragmatist anthropology lines, which moves from but goes beyond Rorty's neo-pragmatism. To this extent, she stresses "the ethical component of Rorty's commitment to bringing into focus the nexus between discursive practices and 
normativity so to be able to argue for the contingent - namely historical - character of normativity itself" (Calcaterra 2019: 110).

Calcaterra argues that Rorty's anthropology draws from Kantian anthropology the centrality of the idea of freedom for human beings. Though, Rorty does not consider "freedom" as an "intrinsic property of human beings or the "rationale-objective foundation' of their moral life," but as "a possibility arrived at via the development of fitting vocabularies and, at the same time, via the practices adequate to the moral character of freedom in the course of human history" (Calcaterra 2019: 116). Elsewhere, she adds that in Rorty's anthropological view, "freedom is a possibility inscribed in human contingency," that is "an internal function" (Calcaterra 2019: 119) of linguistic agents.

On this core subject for new pragmatist anthropology, Calcaterra finds it productive to recover Peirce's tychism to keep together Rorty's "defense of human freedom [...and] the casual character of socio-cultural progress" (Calcaterra 2019: 121). Calcaterra suggests we "consider the 'family resemblance' between the dialectic of chance and regularity advanced by Peirce and the entwining of the notions of regularity, normativity and chance informing Rorty's contingentism" (Calcaterra 2019: 123). She poses the provocative question of whether even Rortyan contingentism might be read as a "metaphysical construction" or at least as a post-modern translation of pragmatist metaphysics for which "reality - human and non-human - is processual, indeterminate and thus also exposed to the control and transformation, even though minimal, that human intelligence can possibly perform upon it" (ibid.). Moreover, she understands the ethical commitment of Rorty's antimetaphysical stance as a way to claim an antiauthoritarian posture in philosophical and scientific debates, say more generally in human conversations. In this perspective, Calcaterra believes that "Peirce's tychism might provide an interesting theoretical integration of the issues at stake in the ethical claim accompanying Rorty's critique of the absolutistic implication of modern metaphysics" (ibid.). She interprets Rorty's anthropology as a way to pursue and extremize the "pragmatist project to overcome traditional foundationalism," that is, "the possibility that chance or, viceversa, regularity/legality, are to be understood as a self-sufficient ontological primum" (Calcaterra 2019: 124). Peirce maintains that "chance/spontaneity implies a certain degree of regularity, which manifests itself in evolutionary continuity," thus revealing that a certain tension between contingency and ethical normativity is characteristic of both the pragmatists' "pluralistic mindset" (Calcaterra 2019: 125) and Rorty's project. As to the Rortyan project, to avoid dismissing normativity and responsibility in a radically contingentist framework, Calcaterra notices how Rorty reshapes this pragmatist tension by continuously implicating both chance and the historicity of human phenomena. Finally, he shapes the notions of human freedom and ethical normativity on a conception of chance as "an opportunity or potentiality opened to and by human initiative" (ibid.). This way, she continues, "human freedom and ethical normativity fuel a philosophical anthropological view in which contingentism converges with an aesthetic meliorism, echoing William James's insight that the possibilities of the human world increase accordingly with the increase of the actual conditions of improvement" (ibid.). According to Calcaterra, James's and Rorty's (deep) humanisms meet. My question entails a further implication of this significant connection. Calcaterra maintains first that "among such 'actual conditions' [Rorty's humanism lists] the formation and development of vocabularies capable of making room for the increase in ethical possibilities," and immediately after she underlines 
"the role granted to the sphere of affections" by Rortyan humanism, to conclude that "Conversation and solidarity are thus one and the same within his contingentism" (Calcaterra 2019: 127). To put it briefly, does the author feel that there is no difference between Rorty's epistemic evaluation of emotions and classic pragmatists' further reliance on the emotional side of experience?

\section{Feminism and Contingentism}

In chapter 5, "Knowing ourselves and recognizing others," Calcaterra constructs an appealing discussion on Rorty's criticized relation with the feminist movement. She argues that "The narrative model of personal identity can be considered as the platform for Rorty's contribution to the debate on feminism" (Calcaterra 2019: 102), which she considers "a specific application of Rorty's linguistic historicism" (Calcaterra 2019: 104). In her view, Rorty stresses the distinction between being a pragmatist and being a realist - thinking about universalism as a synonym of "ethical and epistemological realism" (ibid.) - as two different ways to describe "the acquisition of full personhood" by marginalized groups. Calcaterra shows how Rorty insists on the notion of "semantic authority" as the way groups historically built their "moral identities" and progressively succeeded in "having the language they had developed become part of the language everybody spoke" (TP: 225). Calcaterra envisages Rorty's reliance on what Dewey said about "reality" talking about women's emancipation. According to Dewey, in a very Jamesian fashion, "In philosophy, 'reality' is a term of value or choice" (Dewey 1982: 45). This means that humans always select aspects of the world that support what they judge to be "worth-while," and as already James said in psychology, they elevate these aspects to the status of reality (PP: ch. XXI).

Feminist criticism has addressed the lack of recognition of the importance of economic structures to recognize minorities' identity (cf. Fraser 1997). Besides downsizing this disengaged image of the American philosopher, Calcaterra interprets Fraser's dissatisfaction with Rorty's interventions as due to the "absence of an articulated political philosophy that could serve the most urgent needs of feminism" (Calcaterra 2019: 105). Nevertheless, Calcaterra judges this position as deeply coherent with Rorty's philosophical and ethical-political stance, which she renames "aesthetic meliorism" (Calcaterra 2019: 117, 125; cf. Calcaterra 2014). Following the American democratic tradition, Rorty "justifies democratic politics not through theoretical argumentations but by applying the historicist perspective, according to which the democratic political attitude represents the most valuable choice for the ethical development of mankind" (Calcaterra 2019: 106).

Against the construction of theoretical political models, Rorty supports a conversational model for political changes in which people (including philosophers) "sit down around tables, argue things out and arrive at a reasonable consensus" (ibid.).

As aforementioned, Rorty's relationship with the classic authors of pragmatism is controversial, and particularly Rorty's relation with Dewey is a matter of discussion in feminist debates. Rorty mainly recovers pragmatists' "social hope of emancipation" combined with an "anti-essentialistic attitude" (Calcaterra 2019: 15), but for instance, his controversial distinction between private and public spheres seems to Calcaterra to inevitably mark a distance with Dewey's thought. Her critical reading shows how the Rortyan project aimed at showing the non-predetermined "cohabitation of public and 
private" (Calcaterra 2019: 106). Consequently, responding to the "double ethical" challenge of "preserving individuality from the metaphysical power of the social sphere" and aesthetically improve "the social project of democracy," which means valorize "solidarity as the typical expression of that 'sense of community' seen by Rorty as the core of a public vocabulary" (Calcaterra 2019: 107). This valorization, argues Calcaterra, does not take the private-public connection for granted, but rather contextualizes it under specific historical and aesthetic situations, pragmatically prioritizing the dimension of personal and collective feeling over a disembodied idea of rational choice. This contingentist reading of the possible private-public separation finally seems to lay itself open to Fraser's suspicion of a capitalist infiltration into feminist policies as increasingly "expressed in individual terms" (Calcaterra 2019: 108), and thus no longer engaged in a broader ethical fight for a better world not only for women. According to Calcaterra, this suspicion would be in line with Dewey's demand for radical democracy, therefore far from Rorty's controversial distinction between private and public spheres. Turning to Dewey, Calcaterra sees his conception of democracy as "lifestyle" as dividing because "the pairs individual/social, private/public are just functional and so always revisable categorizations, a revision that must be a characteristic of any democratic community" (Calcaterra 2019: 107). Dewey's refusal of any dichotomic division is an aspect of inevitable disagreement with Rorty, in her reading, at least as to the clarity of their expressions about the interrelation between individual and social stances. However, in a dense passage in which she refers to Medina's Epistemology of Resistance, Calcaterra argues that even assuming that both Dewey and Rorty consider: "the democratic ideal in an indissoluble bond with human emancipation [...] the specifically Deweyan point in the conception of democracy as 'lifestyle' is that it implies the continuous surpassing of the criterion of 'consensus' exactly because it provides an epistemology that makes disagreement productive" (Calcaterra 2019: 107-8). Does this mean that Rortyan and Deweyan views of the interconnection between private and public life ultimately deal with a more or less dialectical (or even conflictive) view of the agreement? In other words, can their difference be seen in relation to Dewey's Hegelian background?

In her preface, Calcaterra confesses that before deciding to write a book on Rorty, she reflected for a long time, given the multitude of voices that are currently rediscovering the American philosopher in different research fields. What can be said in conclusion is that her work significantly contributes to the conversation of humanity wished for by Rorty. Calcaterra's reading deeply enriches the debate on ethical issues and shows a theoretically and historically well informed, balanced, deep, and fascinating reading of Rorty, to which she also contributes with her pragmatist contingentist understanding of philosophical issues. Her's is both a clarifying and deepening work. On the one side, she succeeds in shedding light on some of the most debated Rortyan theories, and on the other, revealing the ethical import and the sophisticated epistemological articulation of some core notions - such as "solidarity" - of Rortyan philosophy, which opens to an original perspective that points to a new pragmatist anthropology going beyond Rorty. 


\section{BIBLIOGRAPHY}

CALCATERRA Rosa M., (2014), “The Linguistic World: Rorty's Aesthetic Meliorism," in

L. Koczanowicz \& K. Liszka (eds.), Beauty, Responsibility and Power, Leiden, Boston, Brill Rodopi, 91-107.

CALCATERRA Rosa M., (2019), Contingency and Normativity. The Challenges of Richard Rorty, BostonLeiden, Brill-Rodopi. [CN].

DEWEY John, (1982), "Philosophy and Democracy," in The Middle Works of John Dewey, vol. 11, ed. by Jo Ann Boydston, Carbondale, Southern Illinois University Press.

FRASER Nancy, (1997), Justice Interruptus: Critical Reflections on the 'Post-socialist' Condition, New York, Routledge.

JAMES William, (1981), The Principles of Psychology, 3 vols, in The Works of William James, edited by F. H. Burkhardt, F. Bowers, and I. K. Skrupskelis, 19 vols, Cambridge, Ma., and London, Harvard University Press. [PP].

RORTY Richard (ed.), (1967/1992), The Linguistic Turn. Recent Essays in Philosophical Method, ChicagoLondon, University of Chicago Press.

RORTY Richard, (1989), Contingency, Irony, and Solidarity, Cambridge, Cambridge University Press. [CIS].

RORTY Richard, (1998), Truth and Progress. Philosophical Papers, vol. 3, Cambridge, Cambridge University Press. [TP].

VOPARIL Chris, (2010), “General Introduction,” in C. Voparil \& R. J. Bernstein (eds.), The Rorty Reader, New York, Wiley-Blackwell.

\section{AUTHOR}

\section{MICHELA BELLA}

Università del Molise

michela.bella[at]unimol.it 